\title{
OPTIMALISASI DISTRIBUSI DAN TINGKAT ENERGI BAHAN PELEDAK DENGAN SISTEM DIFFERENTIAL ENERGY TM (DELTA E)
}

\author{
Stefanus Jagad Gineung Pratidina ${ }^{1)}$, Desy Rachmawati ${ }^{1)}$, Latif Muhammad Badra ${ }^{1)}$, \\ Nur Fajar ${ }^{2)}$, Muhammad Faqih ${ }^{2)}$, Fahri Lundeto ${ }^{2)}$ \\ 1) PT DNX Indonesia \\ ${ }^{2)}$ PT Bukit Makmur Mandiri Utama
}

\begin{abstract}
ABSTRAK
Kondisi geologi yang heterogen menjadi salah satu tantangan pada operasional penggalian dan pengangkutan dalam proses penambangan. Peledakan konvensional sejak lama dilakukan untuk membantu proses pemberaian batuan, namun paradigma yang sampai sekarang masih umum digunakan yaitu bagaimana memakai energi sebesar-besarnya untuk menghancurkan batuan. Hal ini menjadi kurang efisien karena tidak memperhatikan variasi litologi batuan dan masih berpotensi menimbulkan berbagai macam isu, seperti fragmentasi yang buruk, recovery penggalian rendah, serta biaya peledakan yang tinggi. Pemanfaatan bahan peledak dengan tingkat workable energy yang tepat (Berta, 1985) serta distribusinya di dalam lubang berdasarkan jenis litologi dibutuhkan untuk mewujudkan peledakan yang optimal. Teknologi Differential Energy ${ }^{\mathrm{TM}}$ yang mengombinasikan automatic gassing system pada truk MPU (mobile processing unit) dengan high viscosity emulsion product dapat memberikan fleksibilitas dalam pengaturan densitas bahan peledak tanpa mengurangi ketahanan terhadap air. Hal ini memungkinkan pengisian emulsi curah dengan berbagai tingkat energi di dalam satu lubang ledak yang sama secara cepat dan akurat. Selain itu, persentase workable energy yang dihasilkan lebih besar dibanding ANFO maupun bahan peledak emulsi biasa. Makalah ini membahas mengenai tahap 1 penerapan Differential Energy ${ }^{T M}$ dalam operasional peledakan, dimana fokus utamanya yaitu mencapai nilai densitas tunggal yang masih dapat menghasilkan kualitas maksimal. Pengambilan data dilakukan di tambang batubara PT Berau Coal jobsite Buma - Lati yang berada di Kabupaten Berau, Kalimantan Timur dari bulan Agustus 2018 hingga Juli 2019. Hasil yang diperoleh dari studi menunjukkan Differential Energy ${ }^{T M}$ mampu mencapai densitas $0.7 \mathrm{~g} / \mathrm{cc}$ dan memberikan peningkatan dari sisi kualitas fragmentasi peledakan, produktivitas unit digger, nilai recovery, serta pengurangan biaya peledakan akibat penurunan nilai powder factor, penurunan konten AN, dan penerapan expanded pattern. Sistem Differential Energy ${ }^{T M}$ tetap membutuhkan analisis geologi yang komprehensif serta kontrol operasional yang baik. Apabila litologi batuan sudah diketahui maka penempatan bahan peledak dengan tingkat workable energy yang tepat bisa dilakukan, sehingga penggunaan energi bahan peledak bisa lebih efisien dan optimal.
\end{abstract}

Kata kunci: workable energy, distribusi energi, peledakan, Differential Energy ${ }^{T M}$

\begin{abstract}
Heterogeneous geological conditions have become one of the challenges for the operational of excavation and transportation in the mining process. Conventional blasting has long been done to help the process of rock dispersion, but the paradigm that is still commonly used today is how to use maximum energy to destroy rocks. This becomes less efficient because it does not pay attention to variations in rock lithology and still has the potential to cause a variety of issues, such as poor fragmentation, low excavation recovery, and high blasting costs. The use of explosives with the right level of workable energy (Berta, 1985) and their distribution in holes based on the type of
\end{abstract}


lithology are needed to create optimal blasting. Differential Energy ${ }^{T M}$ technology that combines automatic gassing systems in MPU (mobile processing unit) trucks with high viscosity emulsion products can provide flexibility in adjusting the density of explosive without reducing its water resistance. This allows the charging of bulk emulsions with various energy levels for the same explosive hole quickly and accurately. In addition, the percentage of workable energy produced is greater than ANFO or ordinary emulsion explosives. This paper discusses phase 1 of the application of Differential Energy ${ }^{T M}$ in blasting operations, where the main focus is to achieve a single density value that can still produce maximum quality. Data was collected at PT Berau Coal, Buma - Lati jobsite in Berau District, East Kalimantan from August 2018 to July 2019. The results obtained from the study show that Differential Energy ${ }^{T M}$ is able to reach a density of $0.7 \mathrm{~g} / \mathrm{cc}$ and provide an improvement in blasting fragmentation quality, digger unit productivity, blasting recovery value, and reduction in blasting costs due to a decrease in powder factor, decreased AN content, and expanded pattern application. The Differential Energy ${ }^{T M}$ system still requires comprehensive geological analysis and good operational control. If rock lithologies have been detailed then the placement of explosives with the right level of workable energy can be done, so that the use of explosive energy can be more efficient and optimal.

Keywords: workable energy, energy distribution, blasting, Differential Energy ${ }^{T M}$

\section{A. PENDAHULUAN}

Proses peledakan untuk memberai massa batuan dilakukan pada operasi penambangan untuk meningkatkan produktivitas penggalian dan pengangkutan. Kondisi geologi yang heterogen menjadi salah satu tantangan pada operasional penggalian dan pengangkutan dalam proses penambangan. Peledakan konvensional sejak lama dilakukan untuk membantu proses bemberaian batuan untuk meningkatkan produktivitas alat gali maupun angkut, yang mana dalam prosesnya paradigma yang sampai sekarang masih umum yaitu menggunakan energi sebesar-besarnya untuk menghancurkan batuan. Hal ini menjadi kurang efisien karena tidak memperhatikan variasi litologi batuan dan masih berpotensi menimbulkan berbagai macam isu, seperti fragmentasi yang buruk, recovery penggalian rendah, serta biaya peledakan yang tinggi.

Pemanfaatan bahan peledak dengan tingkat workable energy yang tepat (Bertha, 1985) serta distribusinya di dalam lubang berdasarkan jenis litologi dibutuhkan untuk mewujudkan peledakan yang optimal. Teknologi Differential Energy ${ }^{T M}$ atau Delta E yang mengombinasikan automatic gassing system pada truk MPU (mobile processing unit) dengan high viscosity emulsion product dapat memberikan fleksibilitas dalam pengaturan densitas bahan peledak tanpa mengurangi ketahanan terhadap air. Hal ini memungkinkan pengisian emulsi curah dengan berbagai tingkat energi di dalam satu lubang ledak yang sama secara cepat dan akurat. Selain itu, persentase workable energy yang dihasilkan lebih besar dibanding ANFO maupun bahan peledak emulsi biasa. Tidak seperti emulsi pada umumnya yang hanya menggunakan produk densitas tunggal dengan nilai densitas yang cukup tinggi, produk dan teknologi pada Delta E memiliki variasi densitas emulsi yang dapat diturunkan hingga $0.7 \mathrm{gr} / \mathrm{cc}$. Hal ini memungkinkan penyesuaian antara kebutuhan energi dari bahan peledak dan litologi yang ada pada area tersebut.

Makalah ini membahas mengenai tahap 1 penerapan Differential Energy ${ }^{T M}$ dalam operasional peledakan, dimana fokus dan tujuan utamanya yaitu mencapai nilai densitas tunggal yang masih dapat menghasilkan kualitas maksimal sehingga hasil peledakan dari sisi fragmentasi, digging time, produktivitas unit digger dan recovery peledakan dapat tercapai namun dengan mengurangi biaya peledakan dari powder factor serta konten AN. 


\section{B. TINJAUAN LITERATUR}

\section{B.1. Peledakan}

Peledakan merupakan proses penghancuran struktur alamiah batuan sebagai akibat dari efek fisik yang berurutan dari bahan peledak. Peledakan umumnya digunakan pada kegiatan tambang terbuka apabila ditemukan kondisi batuan yang akan dibongkar sifatnya relatif keras sehingga dapat mempengaruhi produktifitas alat gali muat tersebut. Tujuan daripada dilakukan peledakan itu sendiri selain untuk pembongkaran batuan juga bertujuan untuk membuat rekahan dan melepas batuan dari batuan induk dengan menggunakan bahan peledak agar proses pembongkaran batuan dapat berjalan secara efektif dan efisien.

Suatu kegiatan peledakan dikatakan berhasil atau optimal jika memenuhi hal berikut:

1. Target produksi terpenuhi (dinyatakan dalam ton/hari atau ton/bulan)

2. Penggunaan bahan peledak yang efisien, dinyatakan dalam jumlah batuan yang berhasil dibongkar perkilogram bahan peledak (powder factor)

3. Ukuran fragmentasi yang kecil dan seragam

4. Dinding batuan yang. rata dan stabil, tidak overbreak, overhang, retak

5. Dampak terhadap lingkungan minimal

\section{B.2. Fragmentasi}

Fragmentasi menggambarkan distribusi ukuran yang dihasilkan oleh kegiatan peledakan sehingga dapat digunakan pada proses selanjutnya. Faktor yang mempengaruhi fragmentasi antara lain pelepasan energi dari massa batuan dan penggunaan jumlah isian bahan peledak yang tepat.

Ukuran fragmentasi batuan hasil peledakan dapat beraneka ragam karena sifat dari massa batuan dan proses yang terlibat dalam peledakan. Biasanya, formasi batuan yang terjadi tidak homogen dan isotropik dan bahkan dalam skala kecil homogenitasnya bervariasi (Bozic \& Braun, 1991).

Kontrol struktural memiliki pengaruh yang cukup besar pada geomekanis dan sifat dinamis dari formasi batuan. Kekuatan massa batuan cenderung berkurang dengan meningkatnya frekuensi joints dan deformabilitas batuan yang tergantung pada orientasinya. Ini adalah interaksi antara massa batuan dan tekanan yang ditimbulkan akibat detonasi dari bahan peledak yang dapat menghasilkan hasil peledakan yang menguntungkan atau berbahaya. Terkadang bidang joint justru menambah performa dari proses mekanisme peledakan itu sendiri (Gama, 1977) yang nantinya berefek langsung terhadap fragmentasi batuan yang terbentuk.

Fragmen batuan yang berukuran besar (oversized) dapat menjadi masalah dalam kegiatan pasca peledakan karena apabila terjadi maka dibutuhkan penanganan lanjut yang dianggap merugikan karena dibutuhkan secondary blasting untuk memecah batuan kembali. Maka dari itu ukuran fragmentasi batuan yang kecil dan seragam lebih diinginkan karena penanganan selanjutnya akan lebih mudah dan menguntungkan.

\section{B.3. Percepatan Getaran Horizontal}

Transfer energi pada batuan adalah besarnya energi bahan peledak yang diteruskan pada batuan. Energi bahan peledak yang digunakan harus cukup untuk menghancurkan batuan yang akan diledakkan. Apabila energi bahan peledak tidak mencukupi maka peledakan akan menghasilkan fragmentasi yang tidak merata dan banyak menghasilkan boulder. Perhitungan kebutuhan energi untuk menghancurkan dan membongkar batuan dihitung dengan rumus:

a. Jumlah bahan peledak

$$
c=\frac{Q}{H \cdot B . S}\left(\mathrm{~kg} / \mathrm{m}^{3}\right)
$$


Keterangan :

$$
E=c \cdot \mathcal{E}\left(\mathrm{MJ} / \mathrm{m}^{3}\right)
$$

$\mathrm{Q} \quad=$ Jumlah muatan bahan peledak $(\mathrm{kg})$

$\mathrm{H} \quad=$ Tinggi jenjang $(\mathrm{m})$

$\mathrm{B} \quad=\operatorname{Burden}(\mathrm{m})$

$\mathrm{S} \quad=$ Spasi $(\mathrm{m})$

$\mathrm{E}=$ Energi yang dibutuhkan untuk meledakkan $1 \mathrm{~m}^{3}$ batuan

$\mathscr{E} \quad=$ Specific explosion energy

b. Energi yang dibutuhkan untuk menghancurkan batuan

Keterangan :

$$
\varepsilon_{0}=V \cdot s \cdot \mathcal{E}_{s s}
$$

$\mathcal{E}_{0} \quad=$ Energi yang dibutuhkan untuk menghancurkan batuan (MJ)

$\mathrm{V} \quad=$ Volume batuan $\left(\mathrm{m}^{3}\right)$

$\mathrm{s} \quad=$ Permukaan yang baru terbentuk $\left(\mathrm{m}^{2} / \mathrm{m}^{3}\right)$

$\varepsilon_{0} \quad=$ Specific Superfician Energy $\left(\mathrm{MJ} / \mathrm{m}^{2}\right)$

c. Transfer Energi

Menurut Giorgio Berta besarnya transfer energi dapat dihitung dengan rumus:

$$
\mathcal{E} *=\eta_{1} \cdot \eta_{2} \cdot \mathcal{E}
$$

Keterangan :

$$
\begin{array}{ll}
\boldsymbol{\eta}_{1} & =\text { factor impedansi } \\
\boldsymbol{\eta}_{2} & =\text { factor coupling }
\end{array}
$$

Mencari factor Impedansi $\left(\boldsymbol{\eta}_{1}\right)$ :

$$
\eta_{1}=1-\frac{\left(\rho_{r} D-C\right)^{2}}{\left(\rho_{e} D+C\right)^{2}}
$$

Mencari factor coupling $\left(\boldsymbol{\eta}_{2}\right)$ :

$$
\eta_{2}=1-\frac{1}{(e)^{\otimes f / \otimes c}-(e-1)}
$$

Keterangan :

$\mathrm{D} \quad=$ Kecepatan detonasi bahan peledak

$\rho_{r} \quad=$ Densitas batuan $\left(\mathrm{kg} / \mathrm{m}^{3}\right)$

$\rho_{e} \quad=$ Densitas bahan peledak $\left(\mathrm{kg} / \mathrm{m}^{3}\right)$

$\mathrm{C} \quad=$ Cepat rambat gelombang seismic $(\mathrm{m} / \mathrm{s})$

$\otimes f=\otimes c=\mathrm{D}$ lubang ledak $=\mathrm{D}$ isian handak (inch)

d. Energi yang dikeluarkan pada perpindahan batuan Menurut Berta, perpindahan batuan dinyatakan dalam rumus:

$$
1=\frac{1}{3} \sqrt{2\left[\frac{100+a}{100}\right] \frac{B \cdot H}{\operatorname{tg} \Psi}-\frac{B}{2}}
$$

Energi yang dikeluarkan pada perpindahan batuan:

$$
\varepsilon_{c}=V \cdot \rho_{r} \cdot g \cdot \Psi \cdot l .10^{-6} M J
$$


Keterangan :

$\varepsilon_{c} \quad=$ energi yang dikeluarkan pada perpindahan batuan (MJ)

$\mathrm{V} \quad=$ volume batuan

$\rho_{r} \quad=$ density batuan $\left(\mathrm{kg} / \mathrm{m}^{3}\right)$

$\Psi \quad=$ koefisien friksi batuan

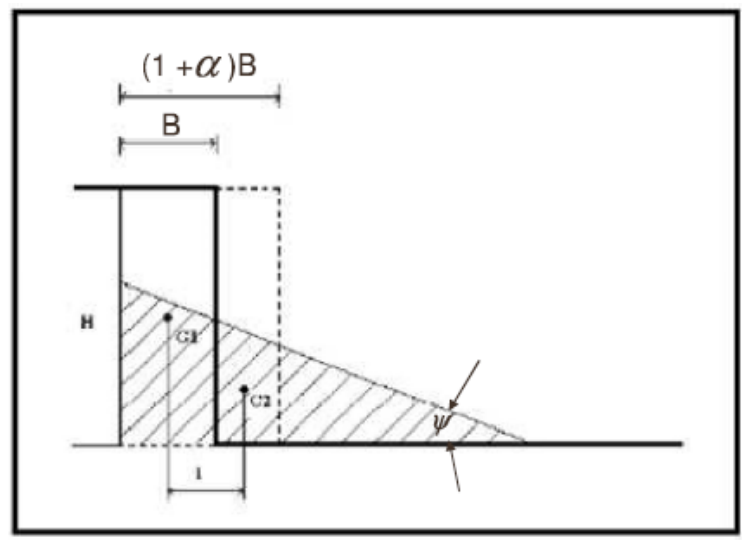

Gambar 1. Perpindahan batuan

Keterangan:

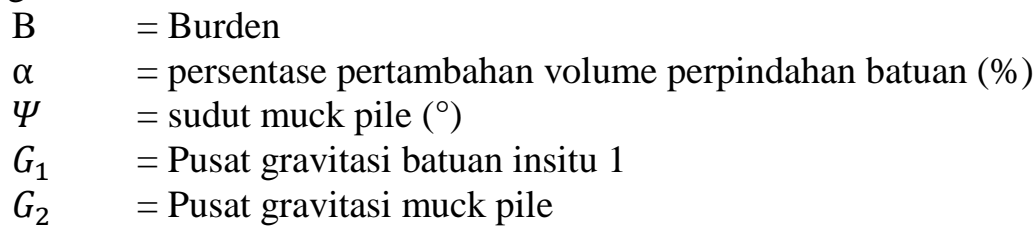

Adanya kesetimbangan energi bahan peledak yang tertransfer pada batuan menyebabkan terjadinya kesetimbangan penyebaran energi, yaitu energi produktif dan energi tidak produktif. Energi produktif yang tertransfer pada batuan akan digunakan untuk:

a. Perpindahan batuan

b. Memecahkan batuan menjadi ukuran yang sesuai dengan target fragmentasi dan relative seraga,

c. Memproyeksikan perpindahan dari batuan terbongkar agar terbentuk tumpukan material hasil peledakan yang baik sehingga kegiatan pemuatan dapat berjalan baik

Sedangkan energi tidak efektif yang tertransfer pada batuan digunakan untuk:

a. Memecahkan batuan secara berlebih

b. Efek-efek peledakan (airblast, ground vibration, dan flyrocks)

\section{B.4. Sistem Teknologi Delta $\mathbf{E}$}

Teknologi Differential Energy ${ }^{T M}$ merupakan sistem yang dapat menyesuaikan energi yang dibutuhkan secara tepat berdasarkan sifat batuan pada area tersebut. Sistem ini mengkombinasikan antara high viscosity emulsion product dan automatic gassing system pada truck MPU (mobile processing unit).

Bulk product pada Differential Energy ${ }^{T M}$ memiliki nilai viskositas hingga $>120,000 \mathrm{cP}$ yang memungkinkan ukuran dari droplet emulsion menjadi lebih kecil dibandingkan emulsi pada umumnya. Dengan nilai viskositas yang tinggi tersebut, produk memiliki nilai kohesi yang besar dan tetap stabil walupun densitas emulsi lebih kecil dibandingkan densitas air.

Terdapat 2 proses mixing system pada Mobile Processing Unit (MPU). Yang pertama adalah proses meningkatkan nilai viskositas produk dan yang kedua adalah Automatic Gassing System, dimana 
pada proses ini nilai densitas produk dapat diatur sesuai litologi secara otomatis dengan pengaturan pada truk.

Kombinasi teknologi tersebut memungkinkan pengisian emulsi curah dengan berbagai tingkat energi di dalam satu lubang ledak yang sama secara cepat dan akurat.

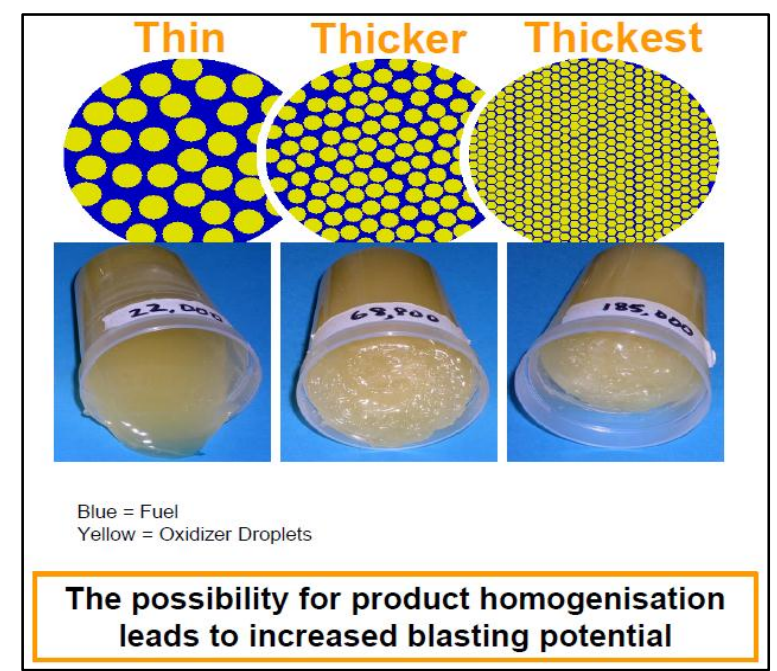

Gambar 2. Perbedaan tingkat homogenisasi produk

\section{METODOLOGI PENELITIAN}

Penelitian peledakan dengan menggunakan emulsi Delta E dilakukan di tambang PT Berau Coal jobsite Buma Lati yang berada di Kabupaten Berau, Kalimantan Timur dari bulan Agustus 2018 hingga Juli 2019. Saat ini terdapat 1 pit besar yang dibagi menjadi beberapa pit yakni Buma 2, Buma 3, Buma 4 dan T6. Masing-masing pit tersebut memiliki karakteristik batuan yang cukup bervariasi yang secara umum terdiri dari sandy (pasiran), clay stone, mud stone, dan sand stone dimana struktur batuan memiliki kecenderungan horizontal bedding. Pada kasus tertentu, model demikian akan mempengaruhi kualitas peledakan jika desain isian atau geometrinya tidak disesuaikan dengan adanya perbedaan perlapisan batuan antara lunak dan keras.

Untuk mengakomodasi tipikal batuan yang cukup bervariasi tersebut, maka digunakan pula variasi geometri peledakan, termasuk di dalamnya burden, spacing, kedalaman lubang, panjang stemming dan panjang isian bahan peledak. Kedalaman lubang ledak divariasikan mulai dari $3 \mathrm{~m}$ sampai 16 $\mathrm{m}$ sesuai dengan kepala batubara, bench design dan jenis alat gali yang digunakan (backhoe atau shovel).

Pengambilan data dibagi menjadi beberapa tahapan. Tahap pertama yaitu tes produk dan pengaturan awal truk MPU yang berfokus pada performa gassing, pengukuran nilai kecepatan detonasi, serta pengambilan data lain seperti fragmentasi, digging time, dan recovery berdasarkan topografi survey. Dari tahap pertama ini didapatkan data untuk densitas produk pada cup $1.1 \mathrm{~g} / \mathrm{cc}$, $1.0 \mathrm{~g} / \mathrm{cc}, 0.9 \mathrm{~g} / \mathrm{cc}$, dan $0.8 \mathrm{~g} / \mathrm{cc}$.

Tahap selanjutnya adalah optimasi desain pattern dan kedalaman untuk mengetahui kualitas peledakan pada lubang dengan kedalaman di atas $12 \mathrm{~m}$ dan juga pattern yang lebih lebar. Burden spasi yang sebelumnya dipakai yaitu 8x9, kemudian dilebarkan menjadi 8x10, 8.5x10, dan 9x10. Densitas yang digunakan secara kontinu adalah $0.8 \mathrm{~g} / \mathrm{cc}$.

Kemudian pada tahap berikutnya target densitas emulsi Delta E pada cup dikurangi lagi menjadi $0.7 \mathrm{~g} / \mathrm{cc}$. Observasi dilakukan sejak bulan Maret 2019 untuk mengetahui konsistensi hasil 
peledakan dengan densitas $0.7 \mathrm{~g} / \mathrm{cc}$. Pada tahap terakhir, dilakukan kembali expand pattern dengan burden spasi menjadi $9.5 \times 10.5$ dan 9x11.

\section{DATA HASIL PENELITIAN}

\section{D.1. Performa Gassing dan Distribusi Energi Vertikal (VED)}

Pengukuran kenaikan kolom isian dari gassing emulsi Delta E dilakukan pada 1.024 lubang dengan kedalaman yang bervariasi mulai dari densitas $1.1 \mathrm{~g} / \mathrm{cc}$ hingga densitas terendah yaitu $0.7 \mathrm{~g} / \mathrm{cc}$. Adapun data diambil secara acak dengan kondisi lubang kering maupun berair. Tabel 1 menunjukkan ringkasan pengukuran kenaikan gassing yang dilakukan sejak bulan Agustus 2018 hingga April 2019.

Tabel 1. Pengukuran kenaikan gassing

\begin{tabular}{cccccc}
\hline $\begin{array}{c}\text { Tinggi Kolom Isian } \\
\text { Sebelum Gassing }(\mathrm{m})\end{array}$ & $1.1 \mathrm{~g} / \mathrm{cc}$ & $1.0 \mathrm{~g} / \mathrm{cc}$ & $0.9 \mathrm{~g} / \mathrm{cc}$ & $0.8 \mathrm{~g} / \mathrm{cc}$ & $0.7 \mathrm{~g} / \mathrm{cc}$ \\
\hline $0-1.9$ & & 0.40 & 0.93 & & 0.93 \\
$2-3.9$ & 0.30 & 0.59 & 1.12 & 1.70 & 1.97 \\
$4-5.9$ & 0.39 & 0.68 & 1.36 & 2.38 & 2.55 \\
$6-7.9$ & 0.53 & 0.87 & 2.17 & 2.80 & 3.35 \\
$8-9.9$ & & 1.43 & 2.31 & 3.46 & 3.25 \\
$\geq 10$ & & 1.77 & 2.75 & & 3.89 \\
\hline
\end{tabular}

Kenaikan kolom isian akibat gassing ini berdampak pada distribusi energi secara vertikal (VED) dimana untuk isian yang sama, emulsi Delta E memberikan persentase VED yang lebih tinggi dibandingkan emulsi konvensional. Pada lubang dengan diameter $200 \mathrm{~mm}$ dan kedalaman $8 \mathrm{~m}$, bahan peledak emulsi dengan densitas $1.15 \mathrm{~g} / \mathrm{cc}$ sebanyak $121 \mathrm{~kg}$ akan mengalami kenaikan kolom isian $0.45 \mathrm{~m}$ setelah gassing sehingga nilai VED-nya 40.6\%. Sementara dengan kondisi lubang dan jumlah isian yang sama, emulsi Delta $\mathrm{E}$ dengan densitas $0.7 \mathrm{~g} / \mathrm{cc}$ mengalami kenaikan kolom isian hingga $2 \mathrm{~m}$ dan nilai VED-nya 60\%. Gambar 2 menampilkan simulasi perbandingan performa gassing antara emulsi konvensional dan emulsi Delta E.

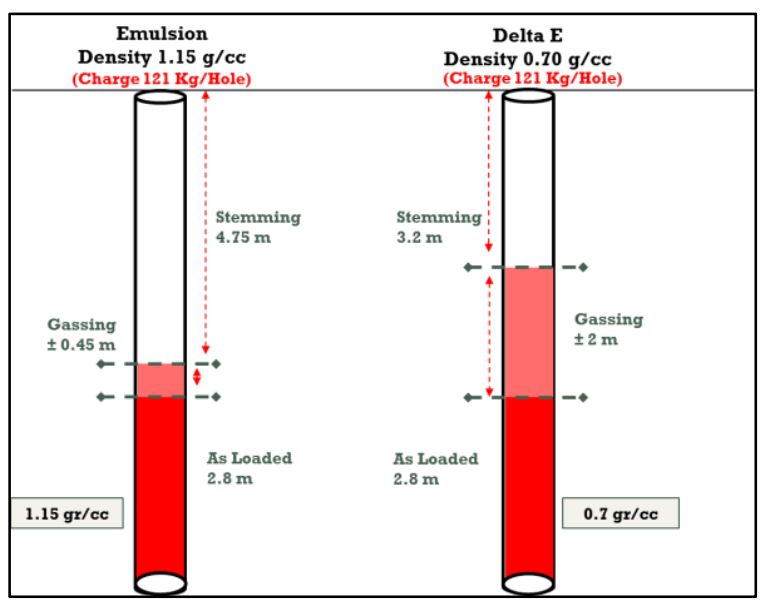

Gambar 3. Perbandingan performa gassing emulsi konvensional dan Delta E

\section{D.2. Velocity of Detonation (VoD)}

Pengukuran kecepatan detonasi (VoD) emulsi Delta E pada studi ini dilakukan menggunakan mesin Shottrack III dengan kabel coaxial Belden RG-59, 75 ohm, 20 AWG, $1000 \mathrm{ft}$ (305 m). Kedalaman lubang ledak bervariasi untuk masing-masing densitas. Tabel 2 menunjukkan rata-rata nilai VoD-nya.

Tabel 2. Nilai VoD untuk tiap densitas

$\begin{array}{llllll}\text { Cup Density }(\mathrm{gr} / \mathrm{cc}) & 1,10 & 1,00 & 0,90 & 0,80 & 0,70\end{array}$




\begin{tabular}{llllll}
\hline Min. VOD (m/s) & 5.079 & 4.740 & 4.648 & 4.566 & 4.469 \\
Max VOD (m/s) & 5.174 & 5.158 & 5.034 & 4.930 & 4.879 \\
Average VOD (m/s) & 5.146 & 4.951 & 4.829 & 4.720 & 4.657 \\
\hline
\end{tabular}

Menurut Barnhart (2004), densitas bahan peledak akan mempengaruhi kecepatan dan tekanan detonasi. Hal ini dapat dilihat dari data tabel di atas dimana semakin kecil densitas, nilai VoD-nya juga semakin berkurang. Namun, produk Delta E tetap bisa menghasilkan rata-rata nilai VoD di atas $4,600 \mathrm{~m} / \mathrm{s}$.

\section{D.3. Fragmentasi Batuan}

Analisis fragmentasi batuan dilakukan dengan menggunakan software WipFrag. Pada studi ini, dilakukan pengukuran fragmentasi untuk membandingkan hasil peledakan dengan emulsi biasa (densitas $1.15 \mathrm{~g} / \mathrm{cc}$ ) dan dengan emulsi Delta E. Kemudian fragmentasi kembali diukur saat dilakukan expand pattern. Tabel 3 menunjukkan hasil fragmentasi peledakan sesuai pattern yang digunakan.

Tabel 3. Fragmentasi batuan sesuai pattern

\begin{tabular}{ccccccc}
\hline \multirow{2}{*}{ Pattern } & \multicolumn{7}{c}{ Fragmentasi P80 (mm) } \\
\cline { 2 - 7 } & $8 \times 9$ & $8 \times 10$ & $8,5 \times 10$ & $9 \times 10$ & $9,5 \times 10,5$ & $9 \times 11$ \\
\hline \multicolumn{1}{c}{ Target } & 500 & 500 & 500 & 500 & 500 & 500 \\
\hline Emulsi (1,15 g/cc) & 454 & - & - & - & - & - \\
Delta E (g/cc) & 272 & 299,4 & 275,2 & 346 & - & - \\
Delta E (g/cc) & - & - & - & 233,6 & 275 & 345 \\
\hline
\end{tabular}

\section{D.4. Digging Time, Produktivitas Digger dan Recovery}

Observasi dan pengambilan data digging time serta produktivitas dilakukan pada excavator dengan jenis PC 4000, CAT 6020, Hitachi 2500, serta shovel Hitachi 3600 untuk densitas cup $0.7 \mathrm{~g} / \mathrm{cc}$.

Dari semua data yang terambil, rata-rata nilainya berada di bawah target 12 detik kecuali pada shovel Hitachi 3600. Hal ini disebabkan data diambil saat proses penggalian di layer terakhir dimana ditemukan digging face pada range $1-2 \mathrm{~m}$. Ringkasan hasil pengukuran dapat dilihat pada Gambar 4 di bawah.

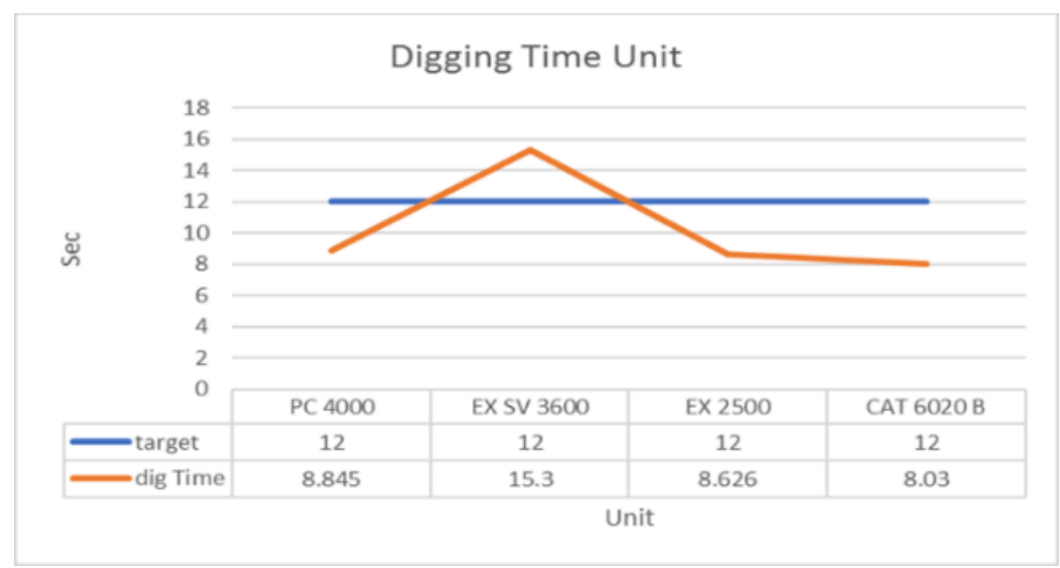

Gambar 4. Digging time berdasarkan jenis unit digger

Sementara itu, hasil aktual produktivitas unit digger dan recovery lokasi peledakan untuk densitas cup $0.7 \mathrm{~g} / \mathrm{cc}$ ditunjukkan pada Gambar 5 dan Gambar 6. 


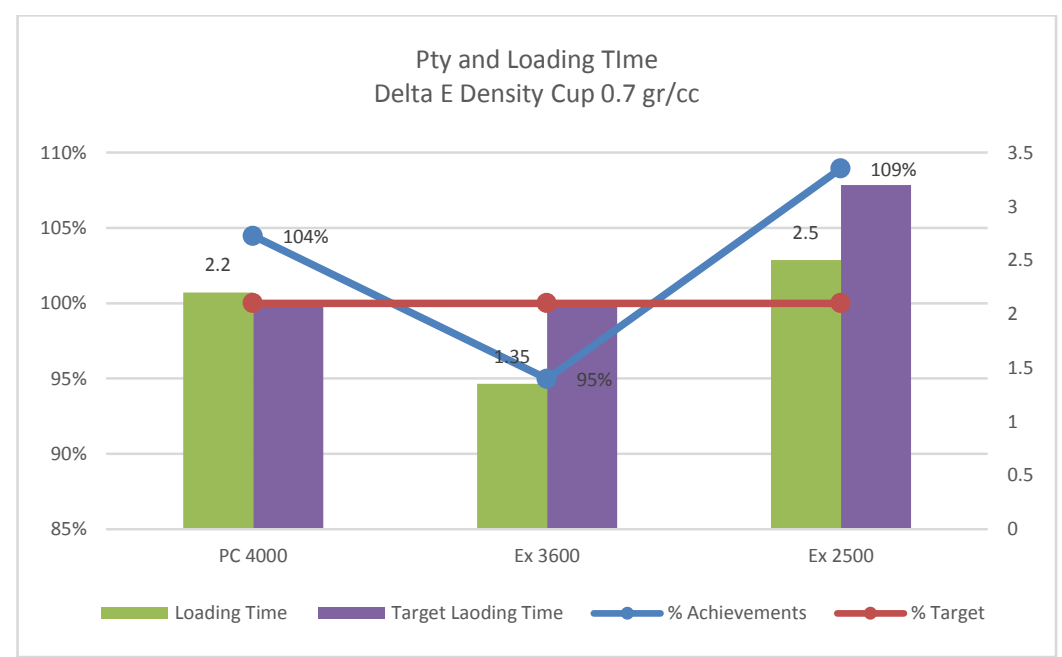

Gambar 5 Produktivitas berdasarkan jenis unit digger

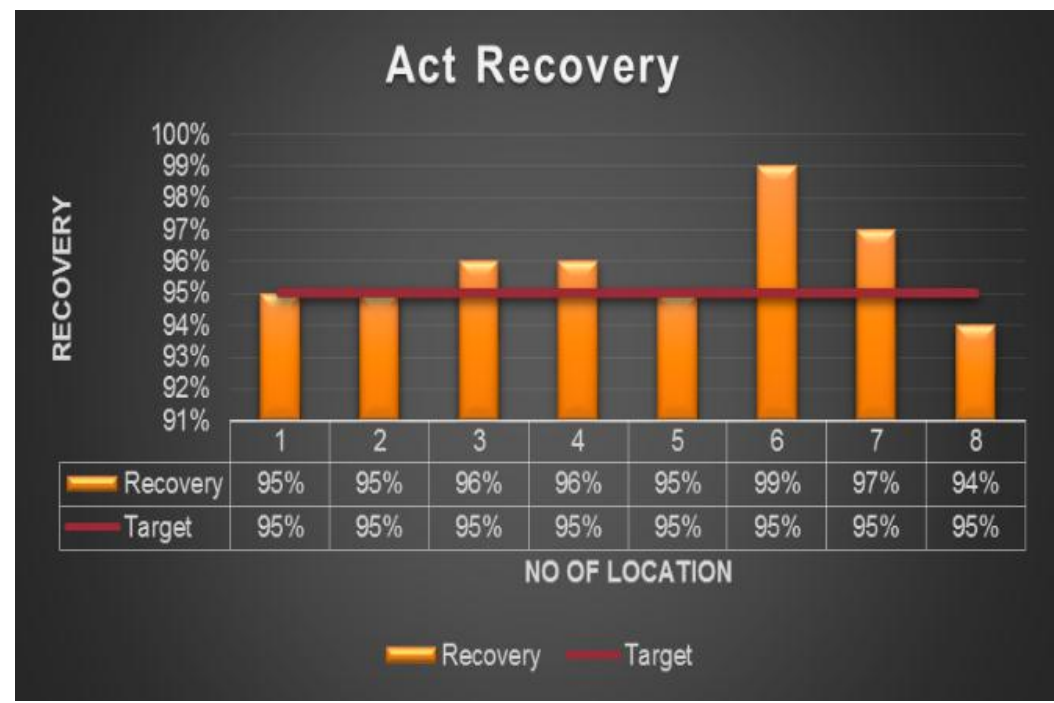

Gambar 6. Recovery aktual lokasi peledakan dengan densitas cup $0.7 \mathrm{~g} / \mathrm{cc}$

Pada tahap terakhir yaitu expand pattern dengan densitas cup $0.7 \mathrm{~g} / \mathrm{cc}$, produktivitas unit dan recovery aktual yang didapat dari semua lokasi trial berada di atas target, yang ditunjukkan pada Gambar 7 dan Gambar 8 berikut.

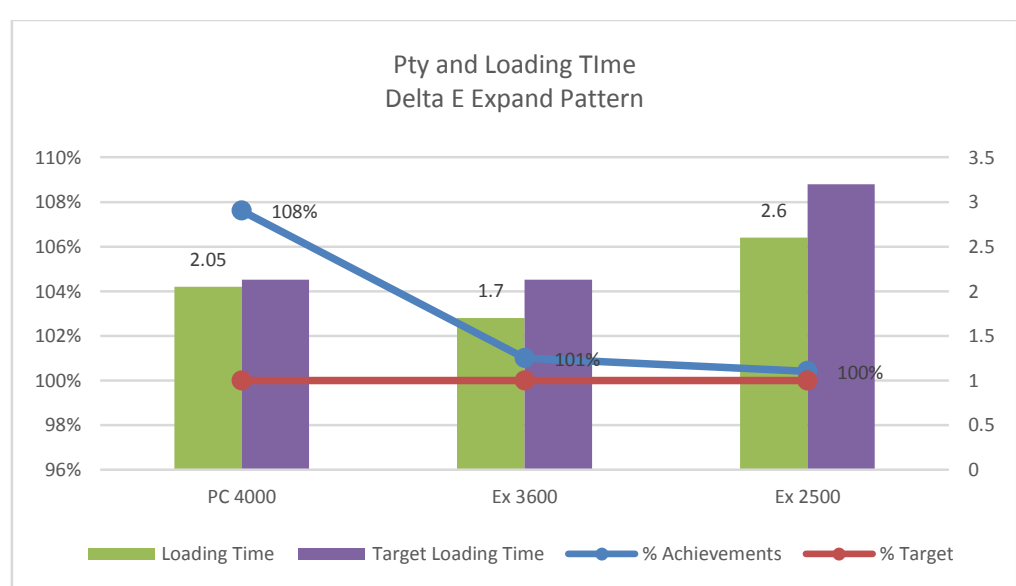

Gambar 7. Produktivitas berdasarkan jenis unit digger pada lokasi expand pattern 


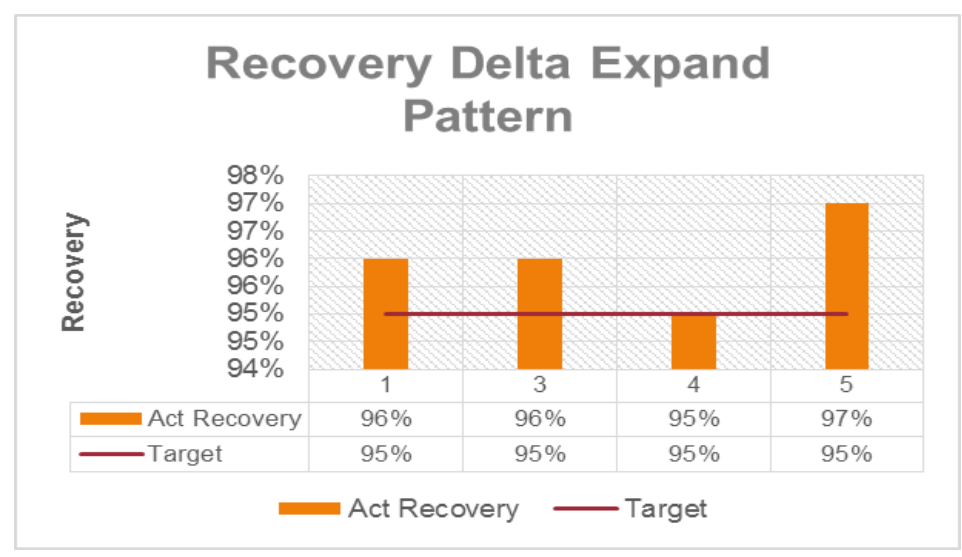

Gambar 8. Recovery aktual lokasi peledakan dengan densitas cup $0.7 \mathrm{~g} / \mathrm{cc}$ expand pattern

\section{D.5. Workable Energy}

Sesuai dengan perhitungan Berta (1985), dapat diketahui besarnya energi bahan peledak yang diteruskan pada batuan. Untuk lubang sedalam 16 meter, penggunaan emulsi Delta E dengan densitas pada cup $0.7 \mathrm{~g} / \mathrm{cc}$ memberikan nilai workable energy yang dapat ditransfer ke batuan sebesar $80.3 \%$. Nilai ini jauh lebih besar dibandingkan dengan emulsi biasa dengan densitas 1.15 $\mathrm{g} / \mathrm{cc}$, yaitu 52\%. Tabel 4 menunjukkan perhitungan persentase workable energy untuk emulsi Delta E dengan densitas di cup $0.7 \mathrm{~g} / \mathrm{cc}$.

Tabel 4. Perhitungan workable energy emulsi Delta E

\begin{tabular}{|c|c|c|c|c|}
\hline \multicolumn{5}{|l|}{ Intact Rock Properties } \\
\hline Rock Type & \multicolumn{2}{|l|}{ Hardzone } & \\
\hline Compressive strength & \multicolumn{2}{|r|}{134} & \multicolumn{2}{|l|}{ Mpa } \\
\hline Tensile Strength & & & \multicolumn{2}{|c|}{$\mathrm{MPa}$} \\
\hline Average Seismic Velocity $(C)$ & & 3933 & \multicolumn{2}{|l|}{$\mathrm{m} / \mathrm{s}$} \\
\hline Density & & 2500 & \multicolumn{2}{|c|}{$\mathrm{kg} / \mathrm{m}^{3}$} \\
\hline \multicolumn{5}{|l|}{ Pattern Design } \\
\hline Drilling Diameter & & 200 & \multicolumn{2}{|l|}{$\mathrm{mm}$} \\
\hline Face Height & & 16 & \multicolumn{2}{|l|}{$\mathrm{m}$} \\
\hline Burden & & & \multicolumn{2}{|l|}{$9 \mathrm{~m}$} \\
\hline Spacing & & 10 & \multicolumn{2}{|l|}{$\mathrm{m}$} \\
\hline Length of Stemming & & 3.5 & \multicolumn{2}{|l|}{$5 \mathrm{~m}$} \\
\hline \multicolumn{5}{|c|}{ Explosives : DELTA E density cup 0,70} \\
\hline Density & \multicolumn{4}{|c|}{$934 \mathrm{~kg} / \mathrm{m}^{3}$} \\
\hline Detonation Velocity & & 4657 & \multicolumn{2}{|l|}{$\mathrm{m} / \mathrm{s}$} \\
\hline Specific Explosion Energy $(\varepsilon)$ & & 2.5 & \multicolumn{2}{|c|}{$\mathrm{MJ} / \mathrm{kg}$} \\
\hline Quantity & & 368.00 & \multicolumn{2}{|l|}{$\mathrm{kg}$} \\
\hline Diameter & & 200 & \multicolumn{2}{|l|}{$0 \mathrm{~mm}$} \\
\hline \multicolumn{5}{|l|}{ TRANSFER OF ENERGY TO THE ROCK } \\
\hline \multicolumn{2}{|l|}{ Volume of the Rock $(V)$} & & \multicolumn{2}{|c|}{\begin{tabular}{|l|l|}
$1440 \mathrm{~m}^{3}$ \\
\end{tabular}} \\
\hline \multicolumn{2}{|l|}{ Fragmentation target } & & \multicolumn{2}{|c|}{$\begin{array}{lll}50 & \mathrm{~cm} \\
\end{array}$} \\
\hline \multicolumn{2}{|c|}{ newly formed surfaces referred to the volume unit $(s)$} & & \multicolumn{2}{|c|}{\begin{tabular}{l|l}
128 & $\mathrm{~m}^{2} / \mathrm{m}^{3}$ \\
\end{tabular}} \\
\hline \multicolumn{2}{|c|}{ Specific superficial energy $\left(\varepsilon_{s s}\right)$} & & 00147 & $\mathrm{MJ} / \mathrm{m}^{2}$ \\
\hline Coeffitien of friction $(\sigma)$ & & & & $1-$ \\
\hline Percentage increase in volume & & & 50 & \\
\hline Angle of Muckpile $(\psi)$ & & & 25 & deg \\
\hline Explosive required to blast $1 \mathrm{~m}^{3}$ & & & 0.26 & $\mathrm{~kg} / \mathrm{m}^{3}$ \\
\hline Energy Shot Required to Blast $1 \mathrm{~m}^{3}$ & (c.E) & & 0.64 & $\mathrm{MJ} / \mathrm{m}^{3}$ \\
\hline Impedance Factor $\left(\eta_{\text {, }}\right)$ & & & 0.85 & \\
\hline Coupling Factor $\left(\eta_{2}\right)$ & & & 1 & if \\
\hline Potential Energy $(Q . \varepsilon)$ & & & 920.00 & MJ \\
\hline Energy Transferred to the Rock $\left(\varepsilon^{*}\right)$ & & & 782.49 & MJ \\
\hline Energy necessary for the crushing & & & 270.95 & $\mathrm{MJ}$ \\
\hline The Forward displacement of the rock & & & 10.12 & $m$ \\
\hline Energy expended in rock movement $(\varepsilon$ & & & 357.44 & MJ \\
\hline$\%$ Energy necessary for the crushing & & & $4.63 \%$ & \\
\hline \% Energy expended in rock movement & $(\varepsilon)$ & & $5.68 \%$ & \\
\hline $\begin{array}{l}\text { \% Ground vibrations, airblast, flyrock } \\
\text { fracture in situ, crushing in the vicinity } \\
\text { deformation of the solid rock behind the }\end{array}$ & $\begin{array}{l}\text { ff the hole } \\
\text { shot }\end{array}$ & & $9.69 \%$ & \\
\hline
\end{tabular}




\section{E. PEMBAHASAN}

\section{Perbandingan Hasil Trial Emulsi Delta E dengan Emulsi Konvensional}

Data yang diperoleh dari hasil trial menunjukkan penggunaan emulsi Delta E mampu memberikan kualitas peledakan yang baik. Densitas emulsi pada cup dapat diturunkan hingga mencapai 0.7 $\mathrm{g} / \mathrm{cc}$, yang artinya akan memberi kenaikan kolom isian yang lebih tinggi. Akibat karakteristik viskositas emulsi Delta E yang kekentalannya melebihi $120,000 \mathrm{cP}$, probabilitas terjadinya dilusi pada produk menjadi kecil.

Kenaikan kolom isian yang tinggi pada lubang berpengaruh terhadap nilai distribusi energi vertikal, dimana untuk isian yang sama dengan emulsi konvensional, persentase VED-nya menjadi lebih besar. Hal ini bisa dimanfaatkan untuk mengoptimalisasi distribusi energi di bagian collar atau zona stemming. Begitupun saat menemukan lapisan capsrock, emulsi Delta E dapat menghancurkan lapisan batuan keras yang berada di bagian atas.

Selain itu, kenaikan kolom isian yang tinggi juga menandakan untuk memperoleh tinggi kolom isian yang sama, jumlah emulsi Delta E yang dibutuhkan di dalam lubang lebih sedikit.

Berdasarkan hasil observasi performa gassing produk emulsi yang sudah dilakukan dalam studi ini, didapat persamaan regresi untuk memprediksi tinggi kenaikan gassing sesuai jumlah emulsi yang diisi ke dalam lubang sebagai berikut,

$$
y=1.7485 x^{0.9013}
$$

Gambar 9 menunjukkan performa gassing dari data observasi.

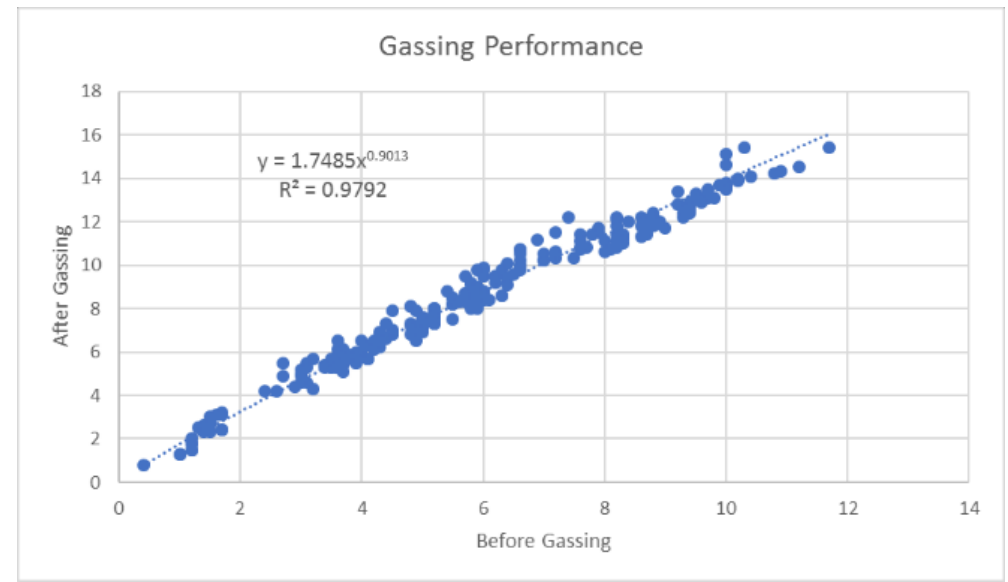

Gambar 9. Performa gassing dari data observasi

Perlu diperhatikan kembali bahwa adanya tekanan hidrostatik di dalam lubang menyebabkan densitas pada cup berbeda dengan densitas aktual di dalam lubang. Selain itu, semakin dalam lubang ledak, semakin tinggi tekanan hidrostatik dan kemampuan detonasi bahan peledak akan berkurang (Sapko et al, 2002). Namun dari hasil pengukuran VoD pada lubang dalam, emulsi Delta E dengan densitas rendah $(0.8 \mathrm{~g} / \mathrm{cc}$ dan $0.7 \mathrm{~g} / \mathrm{cc})$ tetap dapat memberikan nilai $\mathrm{VoD}$ yang baik. Hal ini diakibatkan karena ukuran droplet Delta E yang lebih kecil dan homogen dari emulsi biasa, sehingga produk lebih stabil dan distribusi energinya lebih merata (Allum, 2002).

Pengukuran fragmentasi batuan, digging time, produktivitas digger dan recovery menunjukkan penggunaan emulsi Delta E tetap mampu memenuhi target hasil peledakan walaupun dengan densitas rendah serta pattern yang lebih lebar. Hal lain yang mempengaruhi ini juga adalah tingkat workable energy yang dihasilkan. Sesuai yang tertulis sebelumnya, persentase workable energy Delta E (densitas $0.7 \mathrm{~g} / \mathrm{cc}$ ) mencapai 80.3\%, lebih besar dibanding emulsi biasa (densitas $1.15 \mathrm{~g} / \mathrm{cc}$ ) yang hanya 52\%. Penurunan densitas bahan peledak dan expand pattern yang dilakukan 
menyebabkan nilai powder factor dan total konten AN berkurang. Hal ini secara langsung berdampak pada benefit ekonomi yang didapat. Ringkasan untuk perbandingan nilai powder factor dan total konten AN dari emulsi konvensional dan Delta E dapat dilihat pada Tabel 5.

Tabel 5. Perbandingan PF dan konten AN

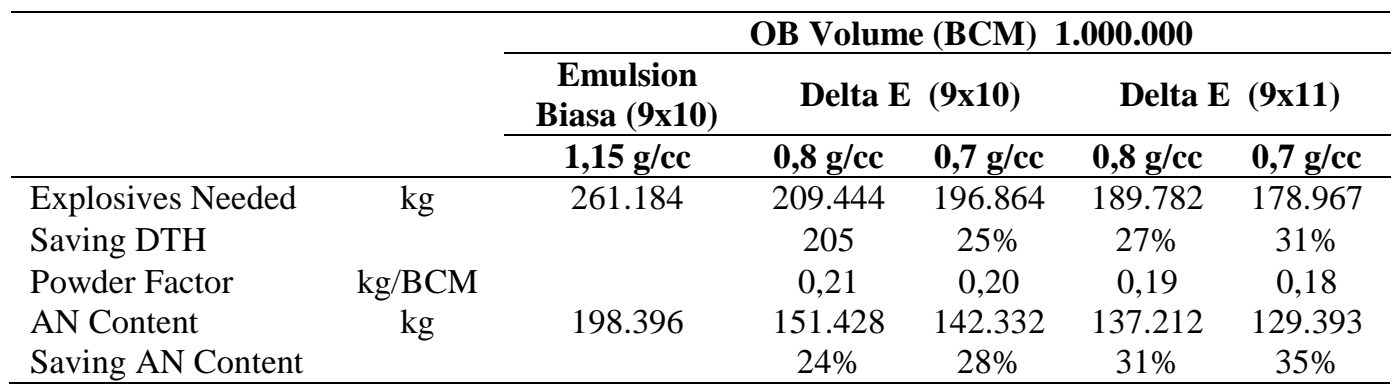

Penelitian ini baru membahas mengenai langkah awal penerapan sistem Delta E dalam operasional peledakan, dimana fokus utamanya yaitu mencapai nilai densitas tunggal yang masih dapat menghasilkan kualitas maksimal. Adanya analisis geologi yang komprehensif sehingga litologi batuan di dalam lubang bisa diketahui serta kontrol operasional yang baik akan bisa menambah lebih banyak keuntungan dan tentunya meningkatkan kualitas hasil peledakan, yaitu dengan mendistribusikan energi bahan peledak dengan tingkat energi yang tepat pada batuan.

\section{F. KESIMPULAN}

Dari analisis yang telah dilakukan, diketahui bahwa sistem Delta E mampu mencapai densitas pada cup hingga $0.7 \mathrm{~g} / \mathrm{cc}$ dan mampu diaplikasikan pada pattern yang lebar (9x11 dan 9.5x 10.5), dimana kualitas peledakan tetap terjaga dengan baik dan mampu memenuhi target, baik dari sisi fragmentasi, digging time, produktivitas digger serta recovery peledakan.

Faktor yang menyebabkan hal ini terjadi yaitu kecepatan detonasi yang masih cukup tinggi (di atas $4,600 \mathrm{~m} / \mathrm{s}$ ), persentase tingkat workable energy yang besar (mencapai $80.3 \%$ ), serta distribusi energi secara vertikal yang lebih tinggi dibanding emulsi konvensional dengan densitas $1.15 \mathrm{~g} / \mathrm{cc}$.

Benefit lain yang didapat dari penggunaan sistem Delta E yaitu pengurangan powder factor serta konten AN sehingga dapat menghemat biaya pengeboran dan peledakan. Improvement lebih lanjut dari aplikasi sistem Delta E dapat dilakukan dengan adanya analisis geologi yang komprehensif untuk mengetahui litologi batuan di dalam lubang sehingga distribusi bahan peledak dengan tingkat energi yang tepat bisa lebih efisien dan optimal.

\section{DAFTAR PUSTAKA}

Allum, J. 2002. A Study of The Behaviour of Emulsion Explosives. Cranfield University, Cranfield.

Barnhart, C. R. 2003. Understanding the "orange smoke" problem in cast blasting. Proceedings of the Twenty-Ninth Annual Conference on Explosives and Blasting Technique, pp 307-318 (International Society of Explosives Engineers: Cleveland, Ohio).

Berta, G. 1985. Explosive: An Engineering Tool. Milano: Italesplosivi int. editions. P 184-185.

Bozic, B. \& Braun, K. 1991. Tectonic Fabric and Blasting in Dolomite Rocks. $7^{\text {th }}$ International Congress on Rock Mechanics: Aachen.

Gama, C. D. 1997. Computer Model for Block Size Analysis of Jointed Rock Masses. Proc. $15^{\text {th }}$ APCOM Symposium AIMM, 305-315: Brisbane. 
Sapko, M, Rowland, J, Mainiero, R and Zlochower, I. 2002. Chemical and physical factors that influence NOx production during blasting-exploratory study. Proceedings of the TwentyEighth Annual Conference on Explosives and Blasting Technique, pp 317-330 (International Society of Explosives Engineers: Cleveland, Ohio). 
PROSIDING TPT XXVIII PERHAPI 2019 